\title{
Field corn yield in response to humic acids application in the absence or presence of liming and mineral fertilization
}

\section{Produtividade de milho em resposta à aplicação de ácidos húmicos na ausência e na presença de calagem e adubação mineral}

\author{
Marihus Altoé Baldotto ${ }^{1 *}$; Raphael Oliveira de Melo; \\ Lílian Estrela Borges Baldotto ${ }^{1}$
}

\begin{abstract}
Corn cultivation continually demands new technologies, since average yields can still be increased. This study aimed to evaluate the response of high-yield corn to humic acids, isolated from organic manure compost, with or without the application of lime and fertilizer. The experiment was conducted at Milhão ${ }^{\circledR}$ (http://www.omilhao.com.br) in Florestal, Minas Gerais State, Brazil. Three treatments were used: (a) control, without liming, fertilization, or humic acids; (b) conventional farm cultivation, with liming and fertilization; (c) liming, fertilization, and humic acids applied to seeds. The experiment design was a randomized block with five replicates (fifteen experimental units). Lime was applied at 1.6 $\mathrm{Mg} \mathrm{ha}^{-1}$, incorporated into total area. Fertilization treatments included $300 \mathrm{~kg} \mathrm{ha}^{-1}$ NPK 08-28-16 at sowing, and $500 \mathrm{~kg} \mathrm{ha}^{-1}$ NPK 20-00-20 in coverage. The concentration of humic acids used in both seed treatment was $10 \mathrm{mmol} \mathrm{L}^{-1}$ of C. Biometrics and biomass productivity were evaluated at harvest time. Humic acids, whether applied as a seed coating, increased yield by $\sim 15 \%$ higher than conventional farm cultivation, and this difference was statistically significant. Therefore, the use of humic acids based plant regulators is positive and complementary to the inputs generally used for corn yield.
\end{abstract}

Key words: Plant production. Soil chemistry and fertility. Plant nutrition. Humic substances.

\section{Resumo}

O cultivo do milho demanda continuamente novas tecnologias, uma vez que a produtividade média pode ainda ser aumentada. O objetivo do presente trabalho foi avaliar a produtividade de milho verde em resposta à aplicação de ácidos húmicos isolados de composto orgânico de esterco bovino em condições de campo, na ausência e presença de calagem e adubação mineral, em lavoura alto rendimento. $\mathrm{O}$ experimento foi desenvolvido na área de produção da empresa O Milhão ${ }^{\circledR}$ (http://www.omilhao.com. br), em Florestal-MG. Foram esquematizados três tratamentos: (a) controle, sem calagem, fertilização e aplicação de ácidos húmicos; (b) cultivo convencional da fazenda, calagem e fertilização; (c) calagem, adubação e aplicação de ácidos húmicos nas sementes. O delineamento experimental foi o de blocos casualizados com cinco repetições (quinze unidades experimentais). Foram aplicados $1,6 \mathrm{Mg} \mathrm{ha}^{-1} \mathrm{de}$ calcário, incorporados em área total. A adubação consistiu na aplicação de $300 \mathrm{~kg} \mathrm{ha}^{-1}$ de NPK 08-28-16 no plantio e de $500 \mathrm{~kg} \mathrm{ha}^{-1}$ de NPK 20-00-20 em cobertura. A concentração de ácidos húmicos usada no tratamento de sementes foi de $10 \mathrm{mmol} \mathrm{L}^{-1}$ de C. A biometria e a produtividade foram avaliadas no momento da colheita do milho. Os resultados mostraram efeitos significativos dos ácidos húmicos

${ }^{1}$ Profs. Drs., Universidade Federal de Viçosa, UFV, Campus Florestal, Instituto de Ciências Agrárias, Florestal, MG, Brasil. E-mail: marihus@ufv.br; lilian.estrela@ufv.br

2 Discente, Curso de Doutorado do Programa de Pós-Graduação em Solos e Nutrição de Plantas, UFV, Viçosa, MG, Brasil. E-mail: raphael.o.melo@ufv.br

* Author for correspondence

Received: Sept. 11, 2018 - Approved: Mar. 19, 2019 
aplicados nas sementes, incrementando cerca de $15 \%$ a produtividade sobre o sistema convencional da fazenda. Assim, o uso de biorreguladores a base de ácidos húmicos é positivo e complementar frente aos insumos geralmente utilizados para a produção de milho.

Palavras-chave: Produção vegetal. Química e fertilidade do solo. Nutrição de plantas. Substâncias húmicas.

In recent years, technological advances in corn production in Brazil have accomplished increases in crop yield although a large gap exists in productivity among farmers. An explanation for this heterogeneity in productivity is that some farmers invest more than others in agricultural technology, including the use of improved seeds, integrated nutrition management, plant protection, and irrigation. An alternative to narrow this gap in corn productivity is the use of plant growth regulators, which stimulate plant metabolism and increase light, water, and nutrient use efficiency (BALDOTTO; BALDOTTO, 2014), as humic substances.

Humic substances are formed during the decomposition of organic matter Piccolo (2001), presenting at the end of the process relatively low molecular weight and are stabilized by hydrophobic interactions at neutral $\mathrm{pH}$, and by $\mathrm{H}^{+}$bonds in acidic solutions. Fragments of humic acids for instance, are formed in response to environmental changes like the release of plant root exudates. Humic acids stimulate seed germination, nutrient uptake, and accelerates root and shoot growth (CANELLAS et al., 2002). Humic acids have beneficial effects when applied to propagating materials such as seeds, cuttings, seedlings, tissue culture and also sprayed on the shoots of cultivated plants (BALDOTTO; BALDOTTO, 2014). The physiological effect of humic acids is partially explained by the structurally resemble of them to plant hormones such auxins, which participates in cell expansion and root initiation, among other physiological effects (CANELLAS; OLIVARES, 2014). The use of humic substances in agriculture has become a viable practice in order to explore the productive potential of crops, and has stimulated the interest of farmers and companies in the agricultural inputs market (CANELLAS; OLIVARES, 2014).
Several studies have investigated the effect of various humic acids on crop growth and development, including corn (BALDOTTO; BALDOTTO, 2014). Most corn experiments have been carried out to determine potential organic compounds to isolate humic acids, rates (MELO et al., 2015) and types of application and their combination with other inputs used in agriculture (BALDOTTO et al., 2016). The results obtained in these experiments are preliminary, carried out in greenhouse conditions, and only the initial corn growth was evaluated (45 days). Thus, it is necessary to test such greenhouse trials results in field conditions.

This objective of the this study is to evaluate corn yield in response to humic acids applications in the absence or presence of liming and mineral fertilization.

The study was conducted in 2013/2014 in the commercial farm located at Florestal, Minas Gerais State, Brazil. The experimental site was situated at latitude $19^{\circ} 53^{\prime} 57^{\prime \prime} \mathrm{S}$ and longitude $44^{\circ} 26^{\prime} 38^{\prime \prime} \mathrm{W}$, at an elevation of $780 \mathrm{~m}$.

Three treatments were used (a) control, without liming, fertilization, or humic acids; (b) conventional farm cultivation, with liming and fertilization; (c) liming, fertilization, and humic acids applied to seeds. The experimental area consisted of four rows with $4.0 \mathrm{~m}$ in length each, spaced $0.85 \mathrm{~m}$ apart, with 5-6 plants. Twenty plants were sampled from each plot. The experimental design was a randomized block with five replicates and a total of fifteen units. Irrigation rates, and the control of weeds, pests and diseases were applied in all treatments when necessary according to the Galvão et al. (2015). The liming requirement was calculated on the basis of soil acidity and the availability of calcium and magnesium (ALVES et 
al., 1999). Lime was applied at the rate of $1.6 \mathrm{Mg}$ $\mathrm{ha}^{-1}$, distributed in total area and incorporated at 20 $\mathrm{cm}$ depth. Conventional fertilization treatment was made with the application of $300 \mathrm{~kg} \mathrm{ha}^{-1}$ of $08-28-16$ (NPK) at sowing, followed by $500 \mathrm{~kg} \mathrm{ha}^{-1}$ of 20-0020 at the 4-8 leaf stage. Humic acids were applied both as a seed treatment at the rate of $10 \mathrm{mmol}$ $\mathrm{L}^{-1}$ of $\mathrm{C}$. This concentration was determined from greenhouse trials conducted earlier (BALDOTTO et al., 2016; MELO et al., 2015). Corn cultivar AG 1051 seeds were soaked in treatment solutions for $16 \mathrm{~h}$. Control seeds were immersed in water.

Acids humic were isolated from cattle manure composted according to the recommendations of EMBRAPA (2001). The isolation of humic acids was performed using the method suggested by the International Humic Substances Society (IHSS, 2017), by preparing a 1: $10(\mathrm{v} / \mathrm{v})$ extract from an organic compound prepared, in a solution of sodium hydroxide $\mathrm{NaOH}$ with a concentration of $0.1 \mathrm{~mol} \mathrm{~L}{ }^{-1}$. After stirring for 4 hours, the extract was decanted, resulting in an insoluble precipitate called the humin fraction (which was not used in this study) and a supernatant solution containing humic and fulvic acids. The $\mathrm{pH}$ of the supernatant was adjusted to between 1 and 1.5, with $6 \mathrm{~mol} \mathrm{~L}^{-1}$ $\mathrm{HCl}$, and the extract was separated, resulting in a supernatant solution containing fulvic acids (also discarded in this study), and a precipitate of humic acids, used as a biostimulant for plants.

Plant height, stem diameter, cob number, diameter and length, weight of cobs with and without straw, plant shoots fresh and dry weight were determined at R3 (milk grain) (Table 1). The results were subjected to analysis of variance (ANOVA) and F-tests were applied at $1 \%, 5 \%$, and $10 \%$ probability (Table 2 ). Contrasts were calculated for these means so that the magnitudes and directions of their differences could be determined. The contrasts are expressed as percentages in table 2 . The results indicated that the treatment of corn plants with humic acids increased crop yield (Tables 1 and 2). These values indicate that the application of humic acids through seed treatment increased the weight of the cob without straw (CWS), independently of presence or absence of liming and mineral fertilization. According to Lopes et al. (2007), the weight of cob without straw (CWS) determines the potential of corn yield, because it is closely associated to grain filling and number of rows of grains per spike

Table 1. Response of different corn plant parts to the applied treatments: Without liming, fertilization, or application humic acids applied to seeds (Control), liming and fertilization without application to humic acids applied to seeds (Lime + Fert), and liming, fertilization, and humic acids applied to seeds (Lime + Fert + AH).

\begin{tabular}{cccccccccc}
\hline Treatment & $\mathrm{H}$ & $\mathrm{SD}$ & $\mathrm{COB}$ & $\mathrm{CD}$ & $\mathrm{CL}$ & $\mathrm{CS}$ & $\mathrm{CWS}$ & $\mathrm{FM}$ & MS \\
\hline & $\mathrm{cm}$ & $\mathrm{mm}$ & number & $\mathrm{mm}$ & $\mathrm{cm}$ & $\mathrm{kg}$ & $\mathrm{kg}$ & \multicolumn{2}{c}{$\mathrm{kg} \mathrm{plant}^{-1}$} \\
Control & 1.70 & 25.00 & 0.50 & 46.00 & 28.00 & 0.46 & 0.187 & 0.392 & 0.152 \\
Lime + Fert & 2.59 & 30.67 & 1.07 & 62.33 & 31.00 & 1.35 & 0.648 & 0.998 & 0.341 \\
Lime + Fert + AH & 2.89 & 30.33 & 1.17 & 64.00 & 28.56 & 1.41 & 0.739 & 0.925 & 0.297 \\
CV (\%) & 7.35 & 4.99 & 10.41 & 3.25 & 2.91 & 11.66 & 17.38 & 10.25 & 17.58 \\
\hline
\end{tabular}

Plant height $(\mathrm{H})$, stem diameter (SD), number of cobs (COB), cob diameter (CD), cob length (CL), weight of cobs with straw (CS), weight of cobs without straw (CWS), plant shoot fresh weight (FM), plant shoot dry weight (MS), Coefficient of variation (CV).

The contrast (-) vs. Lime + Fert (Table 2) show the importance of liming and fertilization in corn, with benefits on agronomic characteristics, such as stem diameter, number of grains of spike, weight of spike with and without straw and, also, increase the mass production of fresh and dry matter. Similar results to these are already widely documented in the literature, and most of them observed in tropical soils. 
Table 2. Average contrasts for plant height (H), stem diameter (SD), number of cobs (COB), cob diameter (CD), cob length (CL), weight of cobs with straw (CS), weight of cobs without straw (CWS), plant shoot fresh weight (FM), plant shoot dry weight (MS) in response to control, without liming, fertilization, or application humic acids (-), liming and fertilization without application to humic acids (Lime + Fert) and liming, fertilization, and humic acids applied to seeds $($ Lime + Fert + AH).

\begin{tabular}{ccccccccccc}
\hline Mean contrast & Diference & $\mathrm{H}$ & $\mathrm{SD}$ & $\mathrm{COB}$ & $\mathrm{CD}$ & $\mathrm{CL}$ & $\mathrm{CS}$ & $\mathrm{CWS}$ & $\mathrm{FM}$ & $\mathrm{MS}$ \\
\hline & & $\mathrm{cm}$ & $\mathrm{mm}$ & number & $\mathrm{Mm}$ & $\mathrm{cm}$ & $\mathrm{kg}$ & $\mathrm{kg}$ & \multicolumn{2}{c}{$\mathrm{kg} \mathrm{plant}^{-1}$} \\
$(-)$ vs. Lime + & numeric & $0.89^{* *}$ & $5.67^{*}$ & $0.57^{* *}$ & $16.33^{\circ}$ & 3.00 & $0.89^{* *}$ & $0.46^{*}$ & $0.61^{* *}$ & $0.19^{* *}$ \\
Fert & RI. \% & $(52)$ & $(23)$ & $(114)$ & $(36)$ & $(11)$ & $(193)$ & $(247)$ & $(155)$ & $(124)$ \\
$(-) v s$. Lime Fert & numeric & $1.19^{* *}$ & $5.33^{\circ}$ & $0.67^{* *}$ & $18^{*}$ & 0.56 & $0.95^{* *}$ & $0.55^{* *}$ & $0.53^{* *}$ & $0.15^{* *}$ \\
+ HA & RI. \% & $(70)$ & $(21)$ & $(134)$ & $(39)$ & $(2)$ & $(207)$ & $(295)$ & $(136)$ & $(95)$ \\
Lime + Fert. $v s$. & numeric & 0.30 & -0.34 & 0.10 & 1.67 & -2.44 & 0.06 & $0.09^{\circ}$ & -0.07 & -0.04 \\
Lime + Fert + AH & RI. \% & $(12)$ & $(1)$ & $(9)$ & $(3)$ & $(8)$ & $(4)$ & $(14)$ & $(7)$ & $(13)$ \\
\hline
\end{tabular}

Significant by the $\mathrm{F}_{\text {-test. }}^{\circ}{ }^{\circ} *$ and $* *$ significant at 10,5 and $1 \%$ probability, respectively

(1) $\mathrm{RI}=$ relative increase $=100(\mathrm{x}-\mathrm{y}) / \mathrm{y}$, where $\mathrm{x}$ is the mean of the treatment with the highest value and $\mathrm{y}$ is the mean of the treatment with the lowest value.

The application of humic acids in corn seed treatment enhanced the effects of liming and fertilization, verified by the largest relative increases (RI. \%) that the contrast (-) vs. HAseed + Fert + Lime compared to the (-) vs. Lime + Fert for most of the growth characteristics, with emphasis on weight of the cob without straw (CWS), 295\% contrary to $245 \%$ of increment on the control for application of HA and non-application of HA respectively. Baldotto et al. (2016) postulated that the application of humic acids can alleviate, at least in part, the costs of liming and fertilization, since the HA increases the nutrient absorption by the plant, and they have the capacity to complex toxic forms of aluminum in the soil. Melo et al. (2015) observed that the application of humic acids isolated from bovine manure in corn seeds increased the contents of $\mathrm{K}$ and $\mathrm{P}$ in 56 and $43 \%$ respectively, in plants cultivate up to 45 days in a greenhouse.

The humicacids applied to the seedsalsoincreased the weight of the cob without straw (CWS) in 14\% when liming and soil fertilization were performed $($ Lime + Fert vs. HAseed + Fert + Lime $),($ table 2), with significance of $\mathrm{p} \leq 0.1$. Baldotto et al. (2016) and Melo et al. (2015) observed positive effects in corn initial vigor (45 days), when seeds of the same hybrid used in the present study where treated with humic acids isolated from bovine manure in the presence of liming and soil fertilization. Therefore, further crop yield gains are possible when they are used in combination compared to conventional fertilization alone. This study directly involved both researchers and growers, and data were generated within the production system itself(MACMILLAN; BENTON, 2014). This approach facilitates achievement of goals and the interpretation of results. It also ensures that experimental findings at all stages of the research are rapidly transmitted to growers and assimilated by them. This fact indicates that the calibration of nutrient doses should indicate the economic optimization of the potential combination of fertilizer and humic acids (BALDOTTO; BALDOTTO, 2014).

The positive effect of humic acids on shoot tissue growth can be explained by physiological factors such as increases in chlorophyll synthesis (BALDOTTO; BALDOTTO, 2014), nutrient uptake (NARDI et al., 2002), root system growth (CANELLAS et al., 2002). To date, there are no reports in the literature that humic acids treatment interferes with the plant metabolism (BALDOTTO; BALDOTTO, 2014). One of the modes of humic acids action is the activation of membrane $\mathrm{H}^{+}$ATPases (CANELLAS et al., 2002; NARDI et 
al., 2002; BALDOTTO; BALDOTTO, 2014; CANELLAS; OLIVARES, 2014). Auxinoid plant hormones have a similar mechanism. It is believed that these compounds increase proton extrusion, which in turn, induces enzymes that increase cell wall plasticity and, consequently, permit cell elongation (CANELLAS et al., 2002).

The results suggest that humic acids used in corn cultivation can increase crop yield. Thus, the results indicate that the use of humic substances in agriculture becomes a possibility to reduce costs, and injury to the environment, considering that the processes for the production of synthetic fertilizers are expensive, and of high cost in energetic terms, besides to use non-renewable sources (TILMAN et al., 2011).

There was a positive interaction between humic acids liming and fertilization; therefore, further yield gains can be achieved by combining these three treatments. Together, they constitute a new development in agricultural technology in corn.

\section{Acknowledgments}

The authors thank FAPEMIG (grant FORTISTCT-10254/2014) for the funding that was awarded.

\section{References}

ALVES, V. M. C.; VASCONCELOS, C. A.; FREIRE, F. M.; PITTA, G. V. E.; FRANÇA, G. E.; RODRIGUES FILHO, A. R.; ARAÚJO, J. M.; VIEIRA, J. R.; LOUREIRO, J. E. Milho. In: RIBEIRO, A. C.; GUIMARÃES, P. T. G.; AlvAREZ, V. H. V. Recomendação para o uso de corretivos e fertilizantes em Minas Gerais. 5. ed. Aproximação. Viçosa, MG: Comissão de Fertilidade do Solo do Estado de Minas Gerais, 1999, p. 314-316.

BALDOtTO, M. A.; BALDOTTO, L. E. B. Ácidos húmicos. Revista Ceres, Viçosa, MG, v. 61, p. 856-881, 2014. Suplemento. DOI: 10.1590/s0034$737 \times 201461000011$

BALDOTTO, M. A.; ROCHA, J. E.; ANDRADE, F. D. P.; DEL GIÚDICE, M. P.; BALDOTTO, L. E. B. Plant stimulant humic acid extracted of organic waste recycled by composting combined with liming and fertilization. Semina: Ciências Agrárias, Londrina, v. 37, n. 6, p. 3955-3964, 2016. DOI: 10.5433/1679-0359

CANELlaS, L. P.; OLIVARES, F. L. Physiological responses to humic substances as plant growth promoter. Chemical and Biological Technologies in Agriculture, Londres, v. 1, n. 1, p. 13-14, 2014. DOI: 10.1186/21965641-1-3

CANELLAS, L. P.; OLIVARES, F. L.; OKOROKOVAFAÇANHA, A. L.; FAÇANHA, A. R. Humic acids isolated from earthworm compost enhances root elongation, lateral root emergence, and plasma membrane H-ATPase activity in roots. Plant Physiology, San Diego, v. 130, n. 4, p. 1951-1957, 2002. DOI: 10.1104/pp.007088

EMPRESA BRASILEIRA DE PESQUISA AGROPECUÁRIA - EMBRAPA. Tratamento e manejo de dejetos de bovinos. Juiz de Fora: EMBRAPA, 2001. 2 p. (Instrução técnica, 52).

GALVÃO, J. C. C.; BORÉM, A.; PIMENTEL, M. A. (Ed.). Milho: do plantio à colheita. Viçosa, MG: Editora UFV, 2015. $382 \mathrm{p}$.

INTERNATIONAL HUMIC SUBSTANCES SOCIETY - IHSS. Natural organic matter research. Isolation of IHSS samples. Madison: Soil Science Society of America, 2017. Available at: www.humicsubstances. Accessed at: 15 nov. 2018.

LOPES, S. J.; LÚCIO, A. D. C.; STORCK, L.; DAMO, H. P.; BRUM, B.; SANTOS, V. J. Relações de causa e efeito em espigas de milho relacionadas aos tipos de híbridos. Ciência Rural, Santa Maria, v. 37, n. 6, p. 15361542, 2007. DOI: $10.1590 / \mathrm{S} 0103-84782007000600005$

MACMILLAN, T.; BENTON, T. G. Engage farmers in research: a new wave of small-scale agricultural innovation will boost yields and protect the planet. Nature, Londres, v. 509, n. 1, p. 25-27, 2014. DOI: $10.1038 / 509025 \mathrm{a}$

MELO, R. O.; BALDOTTO, L. E. B.; BALDOTTO, M. A. Corn initial vigor in response to humic acids from bovine manure and poultry litter. Semina: Ciências Agrárias, Londrina, v. 36, n. 3, p. 1863-1874, 2015. DOI: $10.5433 / 1679-0359$

NARDI, S.; PIZZEGHELLO, D.; MUSCOLO, A.; VIANELLO, A. Physiological effects of humic substances on higher plants. Soil Biology and Biochemistry, Amesterdã, v. 34, n. 11, p. 1527-1536, 2002. DOI: $10.1016 / \mathrm{S} 0038-0717(02) 00174-8$

PICCOLO, A. The supramolecular structure of humic substances. Soil Science, New York, v. 166, n. 1, p. 810832, 2001. DOI: 10.1016/S0065-2113(02)75003-7 
TILMAN, D.; BALZER, C.; HILL, J.; BEFORT, B. L. Global food demand and the sustainable intensification of agriculture. Proceedings of the National Academy of Sciences, Washington, v. 108, n. 50, p. 20260-20264, 2011. DOI: $10.1073 /$ pnas. 1116437108 